\title{
Labeling of packaged foods in Brazil: Use of terms such as homemade, traditional, and the like
}

\author{
Rotulagem de alimentos industrializados no Brasil: \\ uso de termos como caseiro, \\ tradicional e similares
}

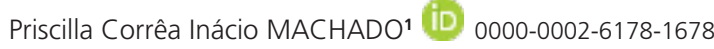 \\ Andréia Martins dos SANTOS 1 (D) 0000-0002-2226-0263 \\ Paula Lazzarin UGGION|² (DD) 0000-0003-2696-0539 \\ Rafaela Karen FABRI² (D) 0000-0001-5282-9951 \\ Jéssica MÜLLER² (D) 0000-0002-7901-6894
}

\section{A B S T R A C T}

\section{Objective}

The study aimed to shed light on the use of the terms "homemade", "traditional", and other similar terms in the front-of-pack labels of industrialized foods.

\section{Methods}

Labels of all packaged foods products $(n=5,506)$ available for sale in a Brazilian supermarket were analyzed. The analysis verified the relative and absolute frequency of terms according to the similarity of expressions and

\footnotetext{
1 Universidade Federal de Santa Catarina, Departamento de Nutrição, Núcleo de Pesquisas de Nutrição em Produção de Refeições. Florianópolis, SC, Brasil.

2 Universidade Federal de Santa Catarina, Departamento de Nutrição, Programa de Pós-Graduação em Nutrição. Campus Reitor João David Ferreira Lima, s/n., Trindade, 88040-900, Florianópolis, SC, Brasil. Correspondência para/Correspondence to: PL UGGIONI. E-mail: <paula.uggioni@ufsc.br>.

Support: Conselho Nacional de Desenvolvimento Científico e Tecnológico and Agência Nacional de Vigilância Sanitária (Processo no 440040/2014-0; Chamada CNPq/ANVISA nº 05/2014).
}

Como citar este artigo/How to cite this article

Machado PCI, Santos AM, Uggioni PL, Fabri RK, Müller J. Labeling of packaged foods in Brazil: Use of terms such as homemade, traditional, and the like. Rev Nutr. 2018;31(1):83-96. https://doi.org/10.1590/1678-98652018000100008 
semantics by food groups according to Brazilian regulation ( $n^{\circ}$ 359/2003). A chi-square test identified differences in the total food terms with terms between food groups $(p<0.001)$.

\section{Results}

Of all foods analyzed, $14.1 \%(n=778)$ presented the target terms. On the analyzed labels, the age of the brand or product was found more frequently $(58.1 \%, n=495)$, followed by the terms "traditional" $(20.1 \%, n=175)$ and "original" $(11.0 \%, n=94)$. The groups that presented the highest relative frequency were groups I (baking goods) and II (canned vegetables), both with $21.4 \%$.

\section{Conclusion}

The study confirmed the commercialization of packaged foods with terms that refer to a traditional and homemade production with different connotations. The information contained in the labels should be clear and correct to ensure that the consumer can make informed choices. The findings indicate the importance of investigating consumers' perception of the presence of these terms on labels and clarifying the composition of these foods.

Keywords: Consumer behavior. Food handling. Food labeling. Industrialized foods. Nutrition.

\section{RE S U M O}

\section{Objetivo}

Este estudo tem como objetivo identificar o uso dos termos caseiro, tradicional e outros similares nos painéis frontais dos rótulos de alimentos industrializados.

\section{Métodos}

Foram analisados rótulos de todos os alimentos industrializados $(n=5506)$ disponíveis para venda em um supermercado brasileiro. Verificou-se frequência relativa e absoluta dos termos de acordo com a similaridade das expressões e semântica, por grupos alimentares, segundo a Resolução n 359/2002. O teste Qui-quadrado foi usado para identificar a diferença no total dos alimentos com termos entre os grupos de alimentos $(p<0,001)$.

\section{Resultados}

Do total de alimentos, $14,1 \%$ ( $n=778)$ apresentaram esses termos. Idade da marca ou produto foi encontrada com maior frequência $(58,1 \% ; n=495)$, seguida pelos termos tradicional $(20,1 \% ; n=175)$ e original $(11,0 \%$; $n=94$ ). Os grupos que apresentaram maior frequência relativa foram o grupo I (produtos de panificação) e II (verduras e conservas), ambos com $21,4 \%$.

\section{Conclusão}

Observou-se a comercialização de produtos industrializados com termos que remetem a uma forma de produção tradicional e caseira, com diferentes conotações. As informações contidas nos rótulos devem ser claras e corretas, para que o consumidor possa realizar suas escolhas conscientemente. Evidencia-se a importância de investigar a percepção dos consumidores quanto à presença desses termos nos rótulos, bem como a composição desses alimentos.

Palavras-chave: Comportamento do consumidor. Processamentos de alimentos. Rotulagem de alimentos. Alimentos industrializados. Nutrição.

\section{INTRODUCTION}

Traditional cuisine has been undergoing food acculturation owing to the globalization and homogenization of contemporary, mainly urban, food $[1,2]$. In this scenario, the loss of cultural identity, standardization of food and product habits, and reduction in regional food consumption, as opposed to the practicality of packaged foods [3], are significant.

The increased consumption of industrialized foods is a global trend $[4,5]$, which, in addition to a modern lifestyle and sedentarism, is considered a contributing factor to the development of 
Chronic Non-Communicable Diseases (CNCD), such as diabetes Mellitus and systemic arterial hypertension [4-8]. Meanwhile, there is growing consumer interest in traditional products [9-12]. International [13] and national efforts [1416] have aimed at promoting a healthy diet that encourages the recovery of cultural food identity and the valuation of food as culture and tradition.

In the contextof promoting healthynutrition, labeling is a tool that ensures consumers' right to information and assists in the formation of choices that account for nutritional aspects and cultural and consumption habits [14]. Studies have shown that consumers read food labels to make healthier choices [17]. According to two systematic reviews, labels are a commonly used tool for the selection of foods $[18,19]$ considered a reliable source of information [19].

As such, the information on food labels must be accurate, standardized, and comprehensible, without denominations and other representations that may render the information incorrect, insufficient, or likely to mislead the consumer as to the nature, composition, quality, or use of the food [20]. The Agência Nacional de Vigilância Sanitária (ANVISA, National Sanitary Surveillance Agency) noted that expressions such as "natural product", "pure", "original", or other equivalent terms should not be used on food labels, as they may mislead the consumer on the nature of the product [21].

However, these terms tend to be used indiscriminately in the food industry. Information in the front-of-pack labels is generally easier to handle than those contained in the back, in addition to the exposed portion on the shelves, racks, and displays of supermarkets [22]. The presence of different terms not provided for by legislation and on the front-of-pack labels may represent a marketing strategy to sell the product by misleading the consumer. Thus, the objective of this study is to identify the use of the terms "homemade", "traditional", "original", and other expressions with this connotation in the front-of-pack labels of packaged foods products commercialized in Brazil.

\section{METHODS}

This cross-sectional, descriptive, and exploratory audit study adopted a qualitativequantitative approach. The labels of all packaged foods products, to which Brazilian nutrition labeling legislation is applicable [23], available for sale during the collection period, were analyzed $(n=5,620)$.

Data collection was performed by previously trained collectors in a supermarket belonging to one of the ten largest Brazilian chain stores, according to the Brazilian Supermarket Association [24]. Samsung ${ }^{\circledR}$ Note 8.0 (Samsung Eletrônica da Amazônia Ltda, Manaus, AM, Brazil) tablets were used. Data collection procedures and data set preparation are described in detail elsewhere [25]. Information was collected regarding the product name, trade name, brand, manufacturer, and country, as well as photographs of all sides of the labels.

A literature research was carried out to identify terms that related food to cultural characteristics, the concept of home, and traditional production, as well as the different senses and meanings attributed to these terms. The literature review was done in Portuguese and English, starting with the following keywords: "alimentos tradicionais", "alimentos caseiros", "alimentos regionais", "alimentos locais", "alimentos coloniais", "alimentos artesanais", "alimentos originais", "rotulagem", "alegação", "traditional food", "homemade", "regional food", "local food", "typical food", "farm-fresh products", "claim", and "labeling". PubMed/ MedLine, Capes, Bireme, Scopus, and Web of Science databases were used for the search, in addition to theses and dissertations and legal documents. To complement the literature search, the "snowball" technique was used in the references found [26]. Terms referring to the 
time the product remained in the market, used in different languages ("desde" and "since"), were also included, as these terms may denote brand or product tradition.

For the analysis of labels, the authors identified the terms found in the literature on the front-of-packs of the labels of packaged foods available in the supermarket. This identification was performed by means of visualization of photographic images of the labels. These terms were then classified as follows: (1) according to the similarity of expressions, (2) according to the food groups as suggested by Brazilian regulation ( $n^{\circ}$ 359/2003 [27]), and (3) according to semantics. The steps used for the analysis of the terms are presented in Figure 1.
The classification of the terms according to the similarity of expression was performed based on the analysis of the presence of similar words on the labels (e.g., traditional and tradition, homemade and homemade product).

The separation of food groups was based on the group categorization in the legislation: group I (baking foods, breads, cereals, legumes, roots, tubers, and related products), II (canned vegetables), III (fruits, juices, syrups, and drink mix), IV (milk and dairy products), $V$ (meat and eggs), VI (oils, fats, and nuts), VII (products in which carbohydrates and fats are the main energy source), and VIII (gravies, sauces, readymade seasonings, broths, and ready-to-eat dishes) [27].

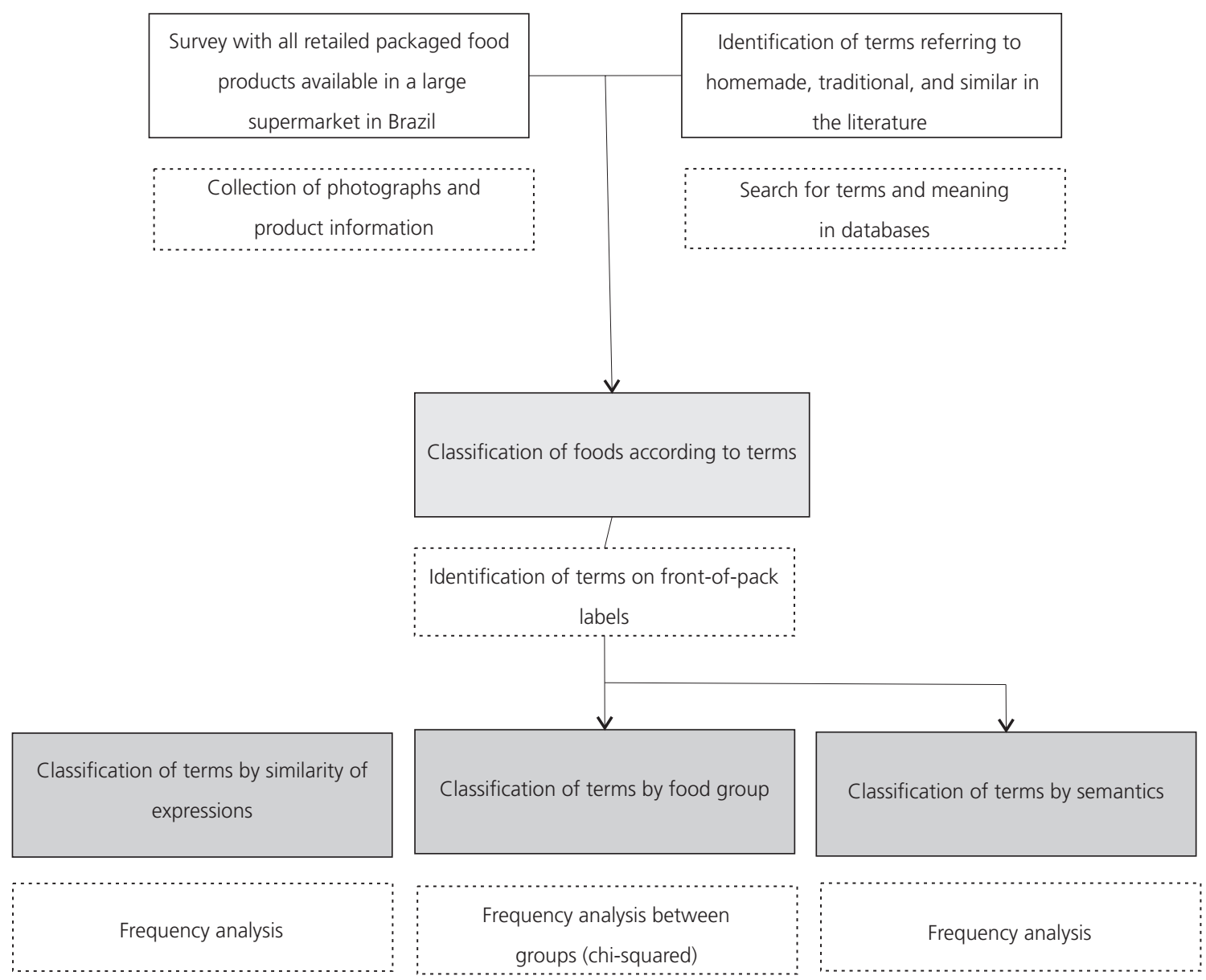

Figure 1. Description of the methodological process used for the analysis of the terms on labels of packaged foods. Florianópolis (SC), Brazil, 2016. 
The classification according to the semantics of expressions involved grouping foods that contained terms with the same connotation, although the terms could be different (e.g., "homemade product" and "hand-made product").

The classification according to similarity of expressions and semantics occurred in an inductive qualitative manner, based on the researchers' perception in relation to the existence of different terms having similar expressions (e.g., home and homey, traditional and tradition) and different terms expressing the same meaning (e.g., tradition and taste, original and taste).

All terms identified were transcribed in an Excel $^{\circledR}$ (Microsoft Corporation, Redmond, Washington (DC), United State of America) worksheet. Foods that presented two or more terms were doubly classified and called mixed foodstuffs.

The data obtained were analyzed using Stata ${ }^{\circledR}$ version 11.0 (StataCorp, College Station, Texas, United States of America), by means of basic descriptive statistics for the analysis of frequency of terms by food groups, described in absolute and relative values. The relative frequency of terms according to the similarity of expressions and in accordance with the semantics was verified. A chi-square test was performed to identify the difference across all foods with terms between the groups. A significance value of $p<0.001$ was set.

The project was assessed and approved by the Human Research Ethics Committee at the Universidade Federal de Santa Catarina, Brazil (Opinion 1.053.080).

\section{RES U L T S}

Of the 5,620 products collected, 114 labels were excluded from the analysis because they did not have photographs in the database $(n=5,506$ labels analyzed). Altogether, 778 foods $(14.13 \%)$ that presented such terms as "homemade", "traditional", or others in their labels were found. Of these, 70 foods had two or more terms on their front labels (called mixed foods). A total of 855 terms were identified on product labels.

According to expression similarity, the group of terms found with the greatest frequency was related to the age of the brand, representing $58.1 \%$ of the terms found. The term "homemade" presented the greatest variety of terms with similarity of expressions, present in 15 different classifications.

In addition to different terms with similarity of expression, the analysis revealed that the food industry has used the same terms having different significance/meanings. Thus, the study chose to separate these terms for greater detail in the analyzed data. This occurred mainly for the term "traditional," which appeared on the labels referring to the taste, a conventional mode of production (in opposition to the organic mode of production), and tradition. The term "original" was used to refer to the taste and being the first type of product launched in the market. The different terms found, grouped by expression similarity, are listed in Table 1.

Groups I (baking foods, breads, cereals, legumes, roots, tubers, and related products) and II (canned vegetables) presented the highest relative frequency of foods with the target terms, both with $21.4 \%$ of products with the target terms, followed by Group VI (milk and dairy products), with $14.4 \%$. The difference in the presence of terms between the groups was considered statistically significant $(p<0.001)$, and in Groups I and II, the prevalence of the terms was four times that in Group IV (Table 2). These data demonstrate that the use of the target terms is more prevalent in some food groups.

Table 3 presents the terms found in each food group. Groups I and VII presented the highest number of the target terms, at 247 and 
Table 1. Number of terminologies related to the terms "homemade", "traditional", and the like, grouped according to the similarity of the expressions. Florianópolis (SC), Brazil, 2016.

\begin{tabular}{|c|c|c|}
\hline Classifications found & $\mathrm{n}$ & $\%$ \\
\hline A) Age of the brand/permanence in the market (total) & 495 & 58.1 \\
\hline "Desde" & 386 & 45.1 \\
\hline Dal & 39 & 4.6 \\
\hline Since & 24 & 2.8 \\
\hline Established & 16 & 2.0 \\
\hline Est & 11 & 1.3 \\
\hline Despuis & 10 & 1.2 \\
\hline Only the year (ex: 1847) & 8 & 1.0 \\
\hline Seit & 1 & 0.1 \\
\hline B) Traditional (total) & 175 & 20.1 \\
\hline Traditional (taste) & 81 & 9.8 \\
\hline Traditional (conventional production) & 40 & 4.8 \\
\hline Tradition & 30 & 3.6 \\
\hline Traditional (tradition) & 20 & 2.4 \\
\hline Family tradition & 4 & 0.5 \\
\hline C) Original (total) & 94 & 11.0 \\
\hline Original (first type of product to be launched in the market) & 57 & 6.7 \\
\hline Original (taste) & 26 & 3.0 \\
\hline Original recipe & 10 & 1.2 \\
\hline Original from Brazil & 1 & 0.1 \\
\hline D) Homemade (total) & 81 & 9.5 \\
\hline Homemade & 20 & 2.3 \\
\hline Homemade taste & 18 & 2.1 \\
\hline Homemade product & 13 & 1.5 \\
\hline Homemade type recipe & 6 & 0.7 \\
\hline Homemade type & 6 & 0.7 \\
\hline From home & 3 & 0.4 \\
\hline Delicious dishes with a homey touch & 3 & 0.4 \\
\hline Well Homemade & 2 & 0.2 \\
\hline Caseirito & 2 & 0.2 \\
\hline Taste of home & 2 & 0.2 \\
\hline Home taste & 2 & 0.2 \\
\hline Taste of homemade & 1 & 0.1 \\
\hline Homemade taste always & 1 & 0.1 \\
\hline With that homemade taste & 1 & 0.1 \\
\hline Grandma's recipe & 1 & 0.1 \\
\hline E) Colonial (total) & 4 & 0.5 \\
\hline Colonial & 3 & 0.4 \\
\hline Colonial product & 1 & 0.1 \\
\hline F) Handmade (total) & 5 & 0.6 \\
\hline Handmade product & 3 & 0.4 \\
\hline Handmade & 2 & 0.2 \\
\hline G) Regional cuisine & 1 & 0.1 \\
\hline Total & 855 & 100.0 \\
\hline
\end{tabular}


Table 2. Classification of packaged foods with the terms "homemade", "traditional", and other similar terms with respect to the groups of foods according to Brazilian regulation (n 359/2003). Florianópolis (SC), Brazil, 2016.

\begin{tabular}{|c|c|c|c|c|c|c|}
\hline \multirow[t]{2}{*}{ Food groups } & \multicolumn{2}{|c|}{ Total food } & \multicolumn{2}{|c|}{$\begin{array}{l}\text { Total food with } \\
\text { terminologies* }^{*}\end{array}$} & \multirow{2}{*}{$\begin{array}{l}\text { Total of } \\
\text { terminologies** }\end{array}$} & \multirow{2}{*}{$\begin{array}{l}\text { Frequency of } \\
\text { terminologies }\end{array}$} \\
\hline & $\mathrm{n}$ & $\%$ & $\mathrm{n}$ & $\%$ & & \\
\hline $\begin{array}{l}\text { I. Baking goods, breads, cereals, legumes, roots, } \\
\text { tubers, and related products }\end{array}$ & 1079 & 19.6 & 231 & 21.4 & 247 & 1.1 \\
\hline II. Canned vegetables & 454 & 8.2 & 97 & 21.4 & 98 & 1.0 \\
\hline III. Fruits, juices, syrups, and drink mix & 270 & 4.9 & 17 & 6.3 & 17 & 1.0 \\
\hline IV. Milk and dairy products & 614 & 11.2 & 33 & 5.4 & 35 & 1.1 \\
\hline V. Meat and eggs & 266 & 4.8 & 31 & 11.7 & 53 & 1.7 \\
\hline VI. Oils, fats, and nuts & 381 & 6.9 & 55 & 14.4 & 57 & 1.0 \\
\hline $\begin{array}{l}\text { VII. Products in which carbohydrates and fats are } \\
\text { the main energy source }\end{array}$ & 1833 & 33.3 & 242 & 13.2 & 268 & 1.1 \\
\hline $\begin{array}{l}\text { VIII. Gravies, sauces, ready-made seasonings, } \\
\text { broths, and ready-to-eat dishes }\end{array}$ & 609 & 11.1 & 72 & 11.8 & 80 & 1.1 \\
\hline Total & \multicolumn{2}{|c|}{5506} & 778 & 14.1 & 855 & - \\
\hline
\end{tabular}

Note: ${ }^{*}$ Chi-squared test of heterogeneity: $p<0.001 ;{ }^{* *}$ This total refers to the sum of the nomenclatures found on food labels, considering the front-of-pack labels that have two or more terminologies (mixed terminology).

258 terms, respectively. Groups III and IV had the lowest presence of the target terms, found in 17 and 35 foods, respectively. The term "desde" (since) (brand or product age) was present in all food groups analyzed. The term "traditional" (taste) appeared 81 times, being absent only in Group III. Another term present in large numbers in the groups was "original" (first type to be launched in the market), with a total of 57 terminologies (Table 3).

In Group I, the terms were found in foods such as cake mixes, breads, and biscuits. In Group II, these were found in sanitized vegetables, vegetable preserves, pulp, and vegetable sauces. Most of the terms referred to the "conventional" mode of production $(n=40)$ that was in contrast to the organic mode of production (e.g., sanitized American lettuce, containing the term "traditional", which refers to the "conventional" production method, being a way of differentiating it from other products with organic production certification).

With regard to Group VI, terms were found in products such as vegetable oils and olive oils, preserved table olives, mayonnaise, and sauces. In Group VII, the terms were present on labels of jams and fruit jellies, sweets, chocolates, and sandwich cookies.

Table 4 shows the classification of the terms in four groups, according to the semantics of expressions found in panels: (1) tradition, (2) variation of taste, (3) mode of production, and (4) homemade taste. This classification revealed terms with different expressions but have the same semantics. For example, the terms "traditional" and "original" both refer to the tradition of a product. This classification was performed after previous analyses in recognition of the fact that the terms were used on food labels with different goals.

The terminologies whose semantics of words referred to tradition were found with the greatest frequency, representing $72.4 \%$ of the terminologies $(n=619)$. Terms that referred to a variation of products of the same line, for example, of different flavors, accounted for $12.5 \% \quad(n=107)$. Reference to the mode of production was found in $10.2 \%$ of terminologies $(n=87)$. The group of terminologies with connotation of homemade taste appeared the least on the front-of-pack labels analyzed, representing $4.9 \%$ of terminologies $(n=42)$. 
Table 3. Classification of packaged foods with the terms "homemade", "traditional", and other similar terms in relation to the food groups according to Brazilian regulation ( $n^{\circ}$ 359/2003). Florianópolis (SC), Brazil, 2016.

\begin{tabular}{|c|c|c|c|c|c|c|c|c|c|}
\hline Terms & I & $\|$ & III & IV & V & $\mathrm{Vl}$ & VII & VIII & Total \\
\hline "Desde" & 112 & 37 & 6 & 10 & 26 & 34 & 129 & 32 & 386 \\
\hline Traditional (taste) & 22 & 11 & - & 14 & 5 & 9 & 15 & 5 & 81 \\
\hline Original (first type to be launched in the market) & 4 & 3 & 8 & 1 & - & - & 41 & - & 57 \\
\hline Dal & 37 & 2 & - & - & - & - & - & - & 39 \\
\hline Traditional (conventional production) & 1 & 39 & - & - & - & - & - & - & 40 \\
\hline Original (taste) & 9 & - & - & 1 & - & 6 & 8 & 2 & 26 \\
\hline Since & - & 1 & - & - & - & 4 & 13 & 6 & 24 \\
\hline Tradition & 5 & - & - & - & 18 & - & - & 7 & 30 \\
\hline Homemade & 8 & - & 1 & - & - & 2 & 2 & 7 & 20 \\
\hline Traditional (tradition) & 11 & 1 & - & 3 & - & - & 4 & 1 & 20 \\
\hline Homemade taste & 17 & - & - & - & - & - & 1 & - & 18 \\
\hline Established & & - & - & - & - & - & 16 & - & 16 \\
\hline Homemade products & 3 & - & - & - & - & - & 6 & 4 & 13 \\
\hline Est & 9 & 1 & - & - & - & - & - & 1 & 11 \\
\hline Depuis & - & - & - & - & - & - & 8 & 2 & 10 \\
\hline Original recipe & - & - & - & - & - & - & - & 10 & 10 \\
\hline Only the year (e.g., 1757) & - & - & - & - & 1 & - & 7 & - & 8 \\
\hline Homemade type recipe & - & - & - & 3 & - & 2 & - & 1 & 6 \\
\hline Homemade type & & 2 & - & - & - & - & 4 & - & 6 \\
\hline Colonial & - & - & - & 3 & - & - & - & - & 3 \\
\hline From home & - & - & - & - & - & - & - & 3 & 3 \\
\hline Handmade product & 3 & - & - & - & - & - & - & - & 3 \\
\hline Your delicious dishes with a touch of homemade & - & - & - & - & - & - & - & 3 & 3 \\
\hline Family tradition & - & - & - & - & 3 & - & 1 & - & 4 \\
\hline Caseirito & - & - & - & - & - & - & - & 2 & 2 \\
\hline Homemade good & - & - & 2 & - & - & - & - & - & 2 \\
\hline Handmade & - & - & - & - & - & - & 2 & - & 2 \\
\hline Home taste & - & - & - & - & - & - & - & 2 & 2 \\
\hline Taste of home & 2 & - & - & - & - & - & - & - & 2 \\
\hline Regional Cuisine & 1 & - & - & - & - & - & - & - & 1 \\
\hline With that homemade taste & - & - & - & - & - & - & - & 1 & 1 \\
\hline Seit & - & 1 & - & - & - & - & - & - & 1 \\
\hline Always homemade taste & 1 & - & - & - & - & - & - & - & 1 \\
\hline Homemade taste & 1 & - & - & - & - & - & - & - & 1 \\
\hline Original of Brazil & - & - & - & - & - & - & 1 & - & 1 \\
\hline Colonial product & 1 & - & - & - & - & - & - & - & 1 \\
\hline Grandma's recipe & - & - & - & - & - & - & - & 1 & 1 \\
\hline Total & 247 & 98 & 17 & 35 & 53 & 57 & 258 & 90 & 855 \\
\hline
\end{tabular}

\section{I S C U S S I O N}

This exploratory study examined how terms with a connotation of homemade, traditional, and the like are used on the labels of marketed foods, indicating a large variety of terms with the same meaning, similar terms being used with different meanings, or even different terms but being used with the same meaning. 
Table 4. Terms "homemade", "traditional", and other similar terms grouped according to the semantics of expressions. Florianópolis (SC), Brazil, 2016.

\begin{tabular}{llc}
\hline Group & \multicolumn{1}{c}{ Terminology } \\
\hline 1) Tradition & $\begin{array}{l}\text { desde, original (first type of product to be launched in the market), dal, tradition, since, } \\
\text { traditional (tradition), established, est, depuis, original recipe, only the year (e.g., 1873), } \\
\text { family tradition, regional cuisine, original from Brazil, Grandma's recipe, seit }\end{array}$ \\
\hline 2) Variation of taste & Traditional (taste), original (taste) \\
\hline 3) Mode of production & $\begin{array}{l}\text { Traditional (conventional production), homemade, homemade products, from home, } \\
\text { colonial, handmade product, handmade, colonial product }\end{array}$ \\
\hline 4) Homemade taste & Homemade taste, homemade type, homemade recipe type, your delicious dishes with \\
& $\begin{array}{l}\text { a touch of homemade, taste of home, caseirito, taste of homemade, homemade taste } \\
\text { always, with that homemade taste }\end{array}$ \\
\hline
\end{tabular}

Source: Prepared by the authors.

Labeling is considered an important information tool for the consumer. The frontof-pack label is usually used by the industry to highlight the positive attributes of food. Some of the features include such terms as "homemade" and "traditional". The Food Standards Agency (FSA), concerned with the use of these terms or the way these descriptions are not clear on the labels, published recommendations of criteria for the use of some terms, such as "pure", "natural", and "traditional", in labeling in the United of Kingdon. The FSA aimed to guide food producers in providing information, assisting authorities in providing advice to the population, helping consumers, and enabling more reliable labeling practices [28].

The FSA also recommends that food should be sold without guile, that is, properly labeled and publicized, to enable potential buyers to make a fair and informed choice based on clear and informative labeling. The information contained in food labels should correspond with the food products' actual characteristics. Appropriate information must be available to show that the use of terms is justified. Moreover, care must be undertaken when marketing terms are included in trade names or fantasy names and in relation to illustrations, to avoid misleading consumers [28].

In Brazil, terms like these are not foreseen and cannot be used in food labeling. Thus, this study aimed to identify how the Brazilian food industry has used terms with marketing potential in the labels of products. As a limitation, we cite the lack of data in the literature on the meanings attributed to the terms investigated. However, we attempted to analyze in different uses of these terms in food labels, grouping them by similarity of expression and semantics, to shed light on the meanings attributed to them.

The term most often used in packaging was the age of the brand, a term provided in several languages (e.g., "desde 1980" and "since 1945"). This approach can be seen as an advertising resource for demonstrating experience and confidence in the brand, and consequently, the marketed product [29]. Hence, this term can induce the consumer to choose the product according to the duration of the brand on the market, even in newly released products still without credibility in the market.

The second most common term group was related to "traditional" and similar expressions. In general, this referred to the traditional taste, when the brand had other variations of the same product (e.g., traditional ketchup and spicy ketchup). Further, the term "traditional" was found to be related to the conventional mode of production (as opposed to the organic mode of production), as previously described in Table 3. Such use of the same term to indicate different meanings may confuse and mislead consumers. 
According to the FSA, the term "traditional" could be used to describe a recipe, fundamental formulation, or processing method for a product that has existed for a significant duration and has consistently contained the traditional ingredients that characterize the product [28]. According to the European Union, to be considered traditional, a food product must have authentic recipes, ingredients, or production processes. In addition, traditional products should have been marketed for at least 50 years in restaurants or other places, apart from the local food history [30]. In other words, they are defined as foods that are part of the tradition of their respective locality.

Thus, it is expected that the term "traditional", when present in food product labels, refers to a mode of production valued by its tradition and by the presence of specific ingredients, among other characteristics that refer to a culture [31]. This study indicated that most of the time, the term is not used in the abovementioned sense. The term "traditional" should not be used to refer to the mode of production, especially if this mode of production is conventional. Conventional production is characterized by the increased use of technologies and large-scale production, combined with the systematic application of agrochemicals in mostly mechanized work processes [32]. In this case, products with an organic mode of production could be related to terms that refer to tradition rather than conventional products, as found in this study, which may lead to consumer misunderstanding. Organic products are strongly associated with higher quality, not only in terms of sustainability [33] but also in nutritional issues [30] and small-scale production [15].

Accordingly, the use of this term in packaged foods is contradictory and problematic, as such products hardly relate to the cultural diversities of a certain place; this may be an advertising strategy to enhance the marketability of a product, without meeting the definition criteria presented previously. For example, the term "traditional"/"tradition" was observed in product labels for artificial vanilla cake and chocolate filling (artificially flavored). One can question which tradition would be related to the production of cakes with artificial flavors, or if it is simply a way of differentiating them from other taste variations, giving credibility to the brand of the product, and/or adding value to the product by referring to a traditional mode of production.

With respect to the term "original", instances of use were found with the connotation of being the first type of product to be launched in the market or as a reference to an original taste or original recipe. The latter applies to such products as powdered chocolate milk and cheese bread. As with the term "traditional", "original" was also used to differentiate between products of the same line with variations in taste.

According to the FSA, the term "original" does not necessarily imply that a product has remained unchanged for a substantial period of time. It can be applied to newer products on the market. This term is used to indicate that a product was the first of its kind to be placed on the market, and therefore distinguishes such product from similar products of new brands [28].

With respect to the term "homemade" and the like, 49 related terms were found. Research conducted by the FSA with consumers in the United Kingdom in 2008 showed that they understand the term "homemade food" as being one that is properly prepared in a home kitchen, instead of a factory [28]. In the labels analyzed, most of the times, these terms did not follow these characteristics. As an example, we can mention the label of a ready-made sauce for salad with homemade terminology. Thus, this term is hardly used in the correct way in packaged foods, especially in the case of ultraprocessed foods. 
Research conducted in the United States of America has examined the meanings of homemade foods by means of interviews with 71 consumers representing different generations. The results highlighted the role of these foods in the separation between family and market and the importance of producer-consumer relations. The presence of the market is reflected in the interviews as a tension between what is industrialized and what is homemade in the form of idealized constructions of "homemade" and lack of market offering. The term "homemade" has often been defined as the absence of the market, a product with unique characteristics that is absent in marketed products. Another issue is the appreciation of those who prepare homemade food, given the existence of a connection between the producer and consumer, which is inaccessible in packaged food. This point suggests the producer's ability to involve meanings in the final product [34].

As such, the expressions associated with "homemadetaste", like "hometaste", "homemade taste", and "taste of home", are being used to draw the attention of the consumer through his/her affective memories of food. Homemade food involves emotion, as well as works with memory and feelings. The expressions "mother's food" and "home cooking" evoke childhood, warmth, security, and lack of sophistication. Both refer to "familiar" [32]. Food traditions, even if incorporated from certain innovations, perhaps because people look for something of the past that they do not find in the present, such as closeness, familiar warmth, and identity, will hardly be provided by fast, impersonal, and solitary meals [35], as is the case in many of the packaged foods analyzed in the present work.

The same can occur with products containing terms related to recipes. Example terms are "grandma's recipe" (for chicken soup), "homemade recipe" (for mayonnaise), and "regional cuisine" (for Japanese-type rice). These terms may also confuse consumers as to the true nature or identity of the product. In addition, the terms may not respect the characteristics of the recipes, which convey a difference from others and are believed to respect the history and cultures of peoples. When a traditional family recipe is prepared, ties, memories, and sensations are recovered, confirming the cohesion among family members [36]. Faced with the consequences of the mechanization process, people once again value what is produced by people or that seem to be produced by them [37]. Similarly, regional kitchens have been decharacterized [38] as a result of progressive globalization, demonstrating the need to recover gastronomic heritage and to value traditional flavors [39].

As to the term "colonial", this has been identified, for example, in the label of a mozzarella cheese product and frozen raw cassava. Colonial products are conceptualized as being products that have gone through some kind of processing and are produced in rural properties, usually by the producer himself/herself or his/her family, by means of an handmade process (e.g., colonial cheese, sausages, salami) [40].

Although traditionally these products must be made in small structures and following the handmade process, to the extent that the goal is to insert the products in the formal market, it seems necessary to change the structure and mode of production to meet legislative parameters. This shift may result in changes not only for the producers but also on the characteristics of the products [41].

As with colonial, the terms "handmade product" and "handmade", in theory, should be considered when the food is produced manually (i.e., by hand, and not industrially) [28]. However, for example, "handmade" was used in the label of a package of potato crisps.

As data collection occurred in a branch of one of the ten largest supermarket networks of Brazil, it can be assumed that this method is one of the reasons for not having found a variety of packaged foods with the terms "handmade" and "colonial", as well as associated with the 
form of production. These foods tend to be marketed in smaller markets or fairs.

In a comparative analysis of the 2001 food label legislation in Brazil, Mercosur, the United Kingdom (UK) and the European Union (EU), highlighted the existence of a large amount of information considered to be misleading, such as the use of ambiguous words and vague phrases [42] (the terms found in the current analysis).

There is an asymmetry of information in the food market in relation to the use of terms in the labels. The lack of specific regulation and, consequently, of supervision can contribute to faults in this scenario. The identification of different terms with the same meaning, or even the same term with different meanings, draws attention to the importance of having clear information on food labels, in addition to highlighting the need to create criteria for the use or prohibition of these terms, to ensure consistency with the actual characteristics of the products. The definition of criteria can facilitate consumer understanding of terms when used in food labels. It can as well guided industry, regulatory, and supervisory bodies, apart from encouraging consumers to fulfill their role in the production chain: demanding foods that are appropriate, considering, above all, the symbolic aspects.

\section{CONCLUSION}

This study, which identified the terminology found in food labels, contributes to the discussion of a topic less explored in scientific literature. It was observed that terms such as "homemade" and "traditional" have been used by the food industry even though it is not provided for in Brazilian labeling legislation, which demonstrates the need for attention to this theme. In addition, the analysis by similarity of expression and semantics demonstrated an absence of standardization in the use of these terms. The study found a wide variety of terms with the same meaning, different terms but with the same meaning, and similar terms with different connotations. The results emphasize the problematic nature of the labeling legislation and the need to improve it.

The use of these terms by the industry requires that, in addition to regulatory and surveillance bodies, consumer associations be attentive to this food segment. Further, health professionals in the food industry and the scientific community should monitor labeling practices. The analysis by food group can help in this process, as it indicated the food groups that merit priority action, terms present in these groups, and food categories in which the terms are present.

The findings of this study may help health professionals and consumers in the use of labeling as a tool to assist in food choice. The conclusions may also provide support for public policy managers and enforcement agencies to improve legislation, particularly by improving the availability of information on food labels.

Further, the study has demonstrated the need for standardization or establishment of criteria for the use of terms on food labels. The use of the target terms can generate expectations among consumers that may not be provided with the purchase; indeed, several studies have highlighted that these terms involve affective and symbolic issues specific to individual consumers. This scenario evidences the importance of investigating consumers' perceptions regarding the meanings of these terms on marketed food labels, as well as their composition. In this respect, the consumer's right to adequate, clear, and concise information should be ensured.

\section{CONTRIBUTORS}

PCI MACHADO, AM SANTOS, PL UGGIONI

were responsible for the design of manuscript; PCI MACHADO, AM SANTOS conducted the data 
collection; RK FABRI, J MÜLLER, PCI MACHADO, AM SANTOS analysed and interpreted the data; RK FABRI, J MÜLLER, PCI MACHADO, PL UGGIONI, AM SANTOS contributed to conduct the research as well as to literature review and have read and approved the final manuscript. PL UGGIONI the coordinator of the project.

\section{REFERENCES}

1. Hernandez JC, Grácia-Arnaiz M. Alimentatión y cultura: perspectivas antropológicas. Barcelona: Ariel; 2005.

2. Diez-Garcia RW. Reflexos da globalização na cultura alimentar: considerações sobre as mudanças na alimentação urbana. Rev Nutr. 2003;16(4):483-92. http://dx.doi.org/10.1590/\$14 15-52732003000400011

3. Poulain JP. Sociologias da alimentação. Florianópolis: Editora da UFSC; 2012. Série Nutrição, 2.

4. Popkin BM, Adair LS, Ng SW. Global nutrition transition and the pandemic of obesity in developing countries. Nutr Rev. 2012;70:3-21.

5. Malik VS, Willet WC, Hu FB. Global obesity: Trends, risk factors and policy implications. Nature Rev Endocrinol. 2013;9(1):13-27.

6. Monteiro CA, Cannon G. The impact of transnational "Big Food" companies on the South: A view from Brazil. PLoS Med. 2012;9(7):1-5.

7. Bermudez IO, Tucker LK. Trends in dietary patterns of Latin American populations. Cad Saúde Pública. 2003;19(1):87-99.

8. Monteiro CA, Levy RB, Claro RM, Castro IRR, Cannon G. A new classification of foods based on the extent and purpose of their processing. Cad Saúde Pública. 2010;26(11):2039-49.

9. Guerrero L, Guàrdia MD, Xicola J. Consumerdriven definition of traditional food products and innovation in traditional foods: A qualitative crosscultural study. Appetite. 2009;52(2):345-54.

10. Pieniack Z, Verbeke W, Vanhonacker F. Association between traditional food consumption and motives for food choice in six European countries. Appetite. 2009;53(1):101-8.

11. Vanhonacker F, Verbeke W, Guerrero L. How European consumers define the 9 concept of traditional food: Evidence from a survey in six countries. Agribusiness. 2010;26(4):453-76.

12. Almli VL, Verbeke W, Vanhonacker $F$, Naes T, Hersleth M. General image and attribute perceptions of traditional food in six European countries. Food Qual Preference. 2011;22(1):129-38.
13. Portinari F. Manifesto Slow Food. Slow Food Brasil; 2013 [acesso 2015 jan 23]. Disponível em: http:// www.slowfoodbrasil.com/slowfood/manifesto

14. Ministério da Saúde (Brasil). Secretaria de Atenção à Saúde. Política Nacional de Alimentação e Nutrição. Brasília: Ministério da Saúde; 2012.

15. Ministério da Saúde (Brasil). Secretaria de Atenção à Saúde. Guia alimentar para a população brasileira. 2a ed. Brasília: Ministério da Saúde; 2014.

16. Ministério da Saúde (Brasil). Secretaria de Atenção à Saúde. Guia alimentar para a população brasileira: promovendo a alimentação saudável. Brasília: Ministério da Saúde; 2006.

17. Viola GCV, Bianchi F, Croce E, Ceretti E. Are food labels effective as a means of health prevention? J Public Health Res. 2016;5(3):139-42.

18. Cowburn G, Stockley L. Consumer understanding and use of nutrition labelling: A systematic review. Public Health Nutr. 2005;8(1):21-8.

19. Campos S, Doxey J, Hammond D. Nutrition labels on pre-packaged foods: A systematic review. Public Health Nutr. 2011;14(8):1496-506.

20. Ministério da Saúde (Brasil). Resolução n. 259 - RDC, de 20 de setembro de 2002. Regulamento técnico para rotulagem de alimentos embalados. Diário Oficial da União. 200220 set.

21. Agência Nacional de Vigilância Sanitária. FAQ: sistema de perguntas e respostas da ANVISA. 2015 [acesso 2015 out 21]. Disponível em: http:// portal.anvisa.gov.br/alimentos5

22. Lima FCC. Comunicação na promoção da alimentação saudável via rótulos: uma análise dos discursos [dissertação]. São Paulo: Faculdade de Saúde Pública; 2014.

23. Ministério da Saúde (Brasil). Agência Nacional de Vigilância Sanitária. Resolução n. 360 - RDC, de 23 de dezembro de 2003. Aprova regulamento técnico sobre rotulagem nutricional de alimentos embalados, tornando obrigatória a rotulagem nutricional. Diário Oficial da União. 200323 dez.

24. Associação Brasileira de Supermercados. Ranking ABRAS 2013. Rev Superhiper. 2013;39(442):130-2.

25. Rodrigues VM, Rayner M, Fernandes AC, Oliveira RC, Proença RPC, Fiates GMR. Comparison of the nutritional content of products, with and without nutrient claims, targeted at children in Brazil. $\mathrm{Br} J$ Nutr. 2015;115(11):2047-56.

26. Ridley D. The literature review: A step-by-step guide for students. 2nd ed. London: Sage; 2008.

27. Ministério da Saúde (Brasil). Agência Nacional de Vigilância Sanitária. Resolução n.359 - RDC, de 23 de dezembro de 2003. Aprova regulamento 
técnico de porções de alimentos embalados para fins de rotulagem nutricional. Diário Oficial da União; 200323 dez.

28. Food Standards Agency. Criteria for the use of the terms fresh, pure, natural etc. in food labelling. London: Food Standards Agency; 2008.

29. Lima FCC. Comunicação na promoção da alimentação saudável via rótulos: uma análise dos discursos [dissertação]. São Paulo: Faculdade de Saúde Pública; 2014.

30. Srednicka-Tober D, Baranski M, Seal C. Composition differences between organic and conventional meat: A systematic literature review and metaanalysis. Br J Nutr. 2016;6(115):994-1011.

31. Traditional United Europe Food. Newsletter of Integrated Project Traditional United Europe Food. Truefood. 2006 [cited 2015 Aug 3];1(1):1. Available from: http://www.truefood.eu/files/publications/ truefoodinfo.pdf

32. Gliessman SR. Agroecology: The ecology of sustainable food systems. Boca Raton: CRC Press; 2014.

33. Tuck SL, Winqvist C, Mota F. Land-use intensity and the effects of organic farming on biodiversity: A hierarchical meta-analysis. J Applied Ecol. 2014;3(7):746-55.

34. Moisio R, Arnould EJ, Price LL. Between mothers and markets. Constructing family identity through homemade food. J Consumer Cult. 2014;4(3):361-84.

35. Maciel ME. Cultura e alimentação ou o que tem a ver macaquinhos de koshima com Brillat-
Savarin? Natureza e cultura. Horiz Antropol. 2001;7(16):145-56.

36. Demeterco SMS. Sabor e saber: livros de cozinha, arte culinária e hábitos alimentares: Curitiba: 1902-1950. Rev Hist Helikon. 2015;2(4):62-77.

37. Ferrucci P. A arte da gentileza: as pessoas mais gentis são mais felizes e bem-sucedidas. 3a ed. Rio de Janeiro: Elsevier; 2004.

38. Fabri RK, Proença RPC, Martinelli SS, Cavali SB. Regional foods in Brazilian school meals. Br Food J. 2015;117(6):1706-19.

39. Uggioni PL, Proença RPC, Zeni LAZR. Assessment of gastronomic heritage quality in traditional restaurants. Rev Nutr. 2010;23(1):7-16. http:// dx.doi.org/10.1590/S1415-52732010000100002

40. Dorigon C, Renk A. Técnicas e métodos tradicionais de processamento de produtos coloniais: de "miudezas de colonos pobres" aos mercados de qualidade diferenciada. Rev Econ Agrícola. 2011;28(1):101-13.

41. Cruz FT, Menashe R. O debate em torno de queijos feitos de leite cru: entre aspectos normativos e a valorização da produção tradicional. Rev Visa Debate. 2014;2(4):34-42.

42. Celeste RK. Análise comparativa da legislação sobre rótulos alimentícios do Brasil, Mercosul, Reino Unido e União Europeia. Rev Saúde Pública. 2001;35(3):217-23.

Received: April 28, 2017

Final version: November 7, 2017 Approved: November 30, 2017 